Рекомендована д. біол. наук, профр. Л. С. Фірою

УДК 612.015.11-02:615.212-099:615.256.3-06:616.36-085.244]-092.9

\title{
ОСОБЛИВОСТІ ПОКАЗНИКІВ ВІЛЬНОРАДИКАЛЬНОГО ОКИСНЕННЯ І АНТИОКСИДАНТНОЇ СИСТЕМИ У ТВАРИН ЗА УМОВ ГОСТРОГО ТОКСИЧНОГО ТА СУБХРОНІЧНОГО УРАЖЕННЯ АЦЕТАМІНОФЕНОМ НА ТЛІ ДОВГОТРИВАЛОГО ЗАСТОСУВАННЯ ЕСТРОГЕНІВ ТА ПРОГЕСТИНІВ ПРИ КОРЕКЦІї ТІОТРИАЗОЛІНОМ ТА ГЕПАДИФОМ
}

\author{
CI. Б. Івануса
}

Тернопільський державний медичний університет імені І. Я. Горбачевського

\begin{abstract}
Резюме: зважаючи на результати досліджень, можна стверджувати про активацію пол у тварин, уражених ацетамінофеном на тлі довготривалого введення естрогенів та прогестинів, свідченням чого є підвищення продукції активних фоорм кисню мононуклеарними лейкоцитами, вмісту продуктів ліпопероксидації: малонового альдегіду, дієнових та трієнових кон'югатів. Здатність коригуючих чинників гальмувати утворення цих продуктів у плазмі та гомогенаті може опосередковано свідчити про антиокиснювальні властивості препаратів, тому становило інтерес дослідити вплив тіотриазоліну та гепадифу на активність цих процесів у щурів, уражених ацетамінофеном на сроні довготривалого введення естрогенів та прогестинів.
\end{abstract}

Ключові слова: ацетамінофен, тіотриазолін, гепадифр, вільнорадикальне окиснення ліпідів і білків, антиоксидантна система.

Вступ. Ацетамінофрен входить до складу більш 200 лікарських засобів під різними торговими марками. Практично всі вони застосовуються як анальгетичні та жарознижувальні засоби $[1,2,3]$. Отруєння відбувається після одноразового приймання великої дози чистого препарату або комбінованих складів, що містять ацетамінофен $[4,5]$. До гострого тяжкого ураження печінки призводить 150-250 мг/кг речовини. Токсичність препарату може наступати в інших випадках навіть при менших дозуваннях. Це зустрічається, якщо організм хворої людини ослаблений або спостерігається дефіцит ваги. Зазвичай це стосується осіб, які дотримуються різних дієтах, страждають від алкоголізму, а також при поєднанні з іншими лікарськими засобами [6-10].

Одними 3 найбільш часто застосовуваних препаратів для лікування захворювань печінки $€$ гепатопротектори. Незважаючи на те, що в більшості країн світу не використовується термін «гепатопротектори», вони широко застосовуються в лікуванні хворих із патологією печінки. Перш за все це речовини, дія яких спрямована на нормалізацію метаболізму, підвищення стійкості до дії патогенних фракторів, нормалізацію фрункціональної активності і стимуляцію репаративнорегенераційних процесів у печінці [11-16].

Зважаючи на це, ми поставили перед собою мету дослідити вплив ацетамінофену на показники вільнорадикального окиснення і антиоксидантної системи у тварин на тлі довготривалого застосування естрогенів та прогестинів при корекції тіотриазоліном та гепадифом.
Методи дослідження. Досліди проводили на бі-

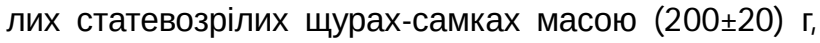
яких утримували на стандартному раціоні віварію та вільному доступі до води.

Нами було проведено 3 серії експериментів. У першій токсичне ураження викликали шляхом одноразового внутрішньошлункового уведення тваринам суспензії ацетамінофену у $2 \%$ розчині крохмалю у дозі 1250 мг/кг маси тіла (1/2 LD50), у другій - суспензію ацетамінофену у $2 \%$ розчині крохмалю у дозі 55 мг/кг, що відповідає вищій терапевтичній дозі, вводили протягом 7-ми діб. Левоноргестрел у $2 \%$ розчині крохмалю тваринам обох серій вводили внутрішньошлунково у дозі 1,17 мг/кг маси тіла, а етинілестрадіол - в дозі 0,23 мг/кг маси тіла протягом 40 діб. Тіотриазолін тваринам вводили внутрішньочеревно в дозі 100 мг/кг. Гепадиф внутрішньоочеревинно в дозі 8,6 мг/кг

У 1 серії експерименту піддослідних щурів поділили на 3 групи: 1-ша - інтактні (контроль); 2-га - уражені ацетамінофеном після 40-добового введення левоноргестрелу та етинілестрадіолу, 3-тя - уражені ацетамінофреном після 40-добового уведення левоноргестрелу, етинілестрадіолу, добового введення тіотриазоліну.

У 2 серії експерименту піддослідних щурів поділили на 3 групи: 1-ша - інтактні (контроль); 2-га тварини, яким уводили ацетамінофен протягом 7-ми діб після 40-ка денного уведення левоноргестрелу та етинілестрадіолу, 3-тя - уражені ацетамінофеном після 40 добового введення левоноргестрелу, етинілестрадіолу, 7 добового введення тіотриазоліну.

ISSN 2312-0967. Pharmaceutical review. 2015. № 2 
У 3 серії експерименту піддослідних щурів поділили на 3 групи: 1-ша - інтактні (контроль); 2-га - тварини, яким уводили ацетаміносен протягом 7-ми діб після 40-добового уведення левоноргестрелу та етинілестрадіолу, 3-тя - уражені ацетамінофеном після 40-добового введення левоноргестрелу, етинілестрадіолу, 7 добового введення гепадифу.

Тварин виводили з експерименту з моменту припинення ураження шляхом евтаназії за умов тіопенталового наркозу. Всі експерименти на щурах проводили відповідно до «Науково-практичних рекомендацій з утриманням лабораторних тварин та роботи 3 ними» [17].

Досліджували цільну кров, сироватку крові й гомогенат печінки. Концентрацію дієнових (ДК) та трієнових (ТК) кон'югатів визначали методом [18], Вміст МА визначали в плазмі або $10 \%$ гомогенаті печінки [19]. Глутатіонпероксидазну активність визначали методом, описаним у роботі [20]. Глутатіонредуктазну активність визначали за кількістю NADPH, що витрачається у ферментативній реакції відновлення окисненого глутатіону [20]. Вміст відновленого глутатіону (Г-SH) досліджували згідно з методикою G. L. Ellman [21]. Інтенсивність окиснювальної модифікації білків визначали виходячи 3 того, що в результаті цього процесу утворюються альдегідні і кетонні групи, які взаємодіють 3 2,4-дисренілгідразином 3 утворенням 2,4-дисеенілгідразонів, що мають характерний спектр поглинання [22]. Альдегідо- і кетопохідні нейтрального характеру реєстрували при $\lambda=370$ нм $\left(\mathrm{OMБ}_{370}\right)$, a основного при $\lambda=430$ нм $\left(\mathrm{OMБ}_{430}\right)$. Активність СОД визначали за загальновизнанним методом [23] у модифрікації [24]. Активність каталази визначали методом [25]. Рівень церулоплазміну визначали методом [26]. Загальну пероксидазну активність крові (ПАК) визначали за методом Т. Попова (1972) [27]. Активні форми кисню, що продукуються мононуклеарними лейкоцитами печінки, проводили методом проточної лазерної цитофрлуориметрії [28]. Кількісні показники обробляли статистично. Достовірність різниці між порівнювальними величинами визначали за t-критерієм Стьюдента.

Результати та обговорення. Як видно із даних таблиці 1 , за дії тіотриазоліну достовірно знижувалась продукція АФК мононуклеарними лейкоцитами, виділеними із печінки уражених щурів. Зокрема, у групі тварин, яким моделювали гостре отруєння ацетаміносреном, зниження відбулося на $29 \%(p<0,05)$ та у групі тварин, яким ацетамінофен вводили впродовж 7 діб у вищій тепапевтичній дозі - на $36 \%(p<0,05)$.

Таблиця 1. Продукція активних фрорм кисню, вміст дієнових та трієнових кон'югатів у щурів за умов гострого токсичного та субхронічного ураження ацетамінофеном після 40-добового застосування етинілестрадіолу і

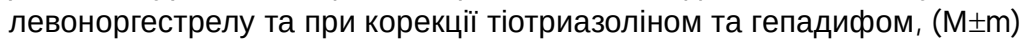

\begin{tabular}{|c|c|c|c|c|c|c|c|c|}
\hline \multirow{3}{*}{ Показник } & \multirow{3}{*}{$\begin{array}{c}\text { Досліджуваний } \\
\text { матеріал }\end{array}$} & \multicolumn{7}{|c|}{ Група тварин } \\
\hline & & \multirow[t]{2}{*}{ 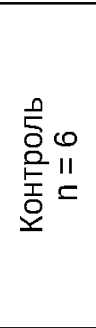 } & \multicolumn{2}{|c|}{$\begin{array}{c}\text { ацетамінофен } \\
\text { після 40-добового } \\
\text { введення } \\
\text { левоноргестрелу } \\
\text { та } \\
\text { етинілестрадіолу } \\
\end{array}$} & \multicolumn{2}{|c|}{$\begin{array}{c}\text { ацетамінофен після } \\
\text { 40-добового введення } \\
\text { левоноргестрелу, } \\
\text { етинілестрадіолу } \\
\text { і корекції } \\
\text { тіотриазоліном }\end{array}$} & \multicolumn{2}{|c|}{$\begin{array}{c}\text { ацетамінофен } \\
\text { після 40-добового } \\
\text { введення } \\
\text { левоноргестрелу, } \\
\text { етинілестрадіолу і } \\
\text { корекції гепадифом }\end{array}$} \\
\hline & & & $\begin{array}{c}\text { одно- } \\
\text { разово } \\
n=6\end{array}$ & $\begin{array}{l}7 \text { діб } \\
\text { n = } 6\end{array}$ & $\begin{array}{c}\text { одно- } \\
\text { разово } \\
n=6\end{array}$ & $\begin{array}{l}7 \text { діб } \\
n=6\end{array}$ & $\begin{array}{c}\text { одно- } \\
\text { разово } \\
n=6\end{array}$ & $\begin{array}{l}7 \text { діб } \\
\mathrm{n}=6\end{array}$ \\
\hline $\begin{array}{l}\text { Активні } \\
\text { форми кисню, } \\
\text { ум. од. } \\
\end{array}$ & $\begin{array}{l}\text { Мононуклеарні } \\
\text { лейкоцити }\end{array}$ & $\begin{array}{c}0,32 \pm \\
0,01\end{array}$ & $\begin{array}{l}0,92 \pm \\
0,02^{*}\end{array}$ & $\begin{array}{l}0,80 \pm \\
0,02^{\star}\end{array}$ & $\begin{array}{l}0,65 \pm \\
0,02^{* \#}\end{array}$ & $\begin{array}{l}0,51 \pm \\
0,01 \text { *\# }\end{array}$ & $\begin{array}{l}0,44 \pm \\
0,02^{\star \#}\end{array}$ & $\begin{array}{l}0,34 \pm \\
0,01^{\#}\end{array}$ \\
\hline $\begin{array}{l}\text { Дієнові } \\
\text { кон'югати, } \\
\text { ум.од./л }\end{array}$ & $\begin{array}{l}\text { Сироватка } \\
\text { крові }\end{array}$ & $\begin{array}{c}1,11 \pm \\
0,03\end{array}$ & $\begin{array}{l}4,43 \pm \\
0,51^{\star}\end{array}$ & $\begin{array}{l}3,19 \pm \\
0,64^{*}\end{array}$ & $\begin{array}{l}1,94 \pm \\
0,23^{\#}\end{array}$ & $\begin{array}{c}1,69 \pm \\
0,37\end{array}$ & $\begin{array}{l}1,56 \pm \\
0,09 \#\end{array}$ & $\begin{array}{c}1,22 \pm \\
0,11\end{array}$ \\
\hline $\begin{array}{l}\text { Дієнові } \\
\text { кон'югати, } \\
\text { ум.од./кг } \\
\end{array}$ & $\begin{array}{l}\text { Гомогенат } \\
\text { печінки }\end{array}$ & $\begin{array}{c}6,24 \pm \\
0,24\end{array}$ & $\begin{array}{c}17,67 \pm \\
1,48^{\star}\end{array}$ & $\begin{array}{c}10,76 \pm \\
0,96^{*}\end{array}$ & $\begin{array}{l}9,44 \pm \\
1,31^{\star \#}\end{array}$ & $\begin{array}{l}7,49 \pm \\
0,91^{\#}\end{array}$ & $\begin{array}{l}8,32 \pm \\
0,43^{\star \#}\end{array}$ & $\begin{array}{l}6,76 \pm \\
0,38^{\#}\end{array}$ \\
\hline $\begin{array}{l}\text { Трієнові } \\
\text { кон'югати, } \\
\text { ум.од./л }\end{array}$ & $\begin{array}{l}\text { Сироватка } \\
\text { крові }\end{array}$ & $\begin{array}{c}0,61 \pm \\
0,01\end{array}$ & $\begin{array}{l}4,16 \pm \\
0,85^{\star}\end{array}$ & $\begin{array}{l}2,73 \pm \\
0,70^{\star}\end{array}$ & $\begin{array}{l}1,69 \pm \\
0,34^{* \#}\end{array}$ & $\begin{array}{l}1,04 \pm \\
0,08^{\star \#}\end{array}$ & $\begin{array}{l}1,11 \pm \\
0,08^{\star \#}\end{array}$ & $\begin{array}{l}0,84 \pm \\
0,05^{\star \#}\end{array}$ \\
\hline $\begin{array}{l}\text { Трієнові } \\
\text { кон'югати, } \\
\text { ум.од./кг }\end{array}$ & $\begin{array}{l}\text { Гомогенат } \\
\text { печінки }\end{array}$ & $\begin{array}{c}3,75 \pm \\
0,09\end{array}$ & $\begin{array}{l}8,27 \pm \\
0,87^{\star}\end{array}$ & $\begin{array}{l}5,29 \pm \\
0,63^{\star}\end{array}$ & $\begin{array}{l}4,62 \pm \\
0,83^{\#}\end{array}$ & $\begin{array}{c}4,25 \pm \\
0,54\end{array}$ & $\begin{array}{l}4,23 \pm \\
0,47^{\#}\end{array}$ & $\begin{array}{l}3,66 \pm \\
0,38^{\#}\end{array}$ \\
\hline
\end{tabular}

Примітка:

* - різниця вірогідна щодо контрольних тварин;

\# - різниця вірогідна щодо тварин, уражених ацетамінофреном після 40- добового введення левоноргестрелу та етинілестрадіолу.

ISSN 2312-0967. Фармацевтичний часопис. 2015. № 2 
Аналогічно змінювались і показники вмісту дієнових та трієнових кон'югатів у плазмі крові і печінці тварин.

У плазмі крові тварин, яким після одноразового введення ацетамінофену на фроні 40-добового введення естрогенів і прогестинів уводили тіотриазолін, концентрація дієнових кон'югатів вірогідно зменшилась у плазмі крові на 174,8 \%, у печінці - на 151,3 \%, порівняно з ураженими тваринами, яким корекцію не проводили, а вміст трієнових кон'югатів - відповідно, на 277 та 123 \%. У плазмі крові тварин, яким після введення ацетамінофену впродовж 7 діб на фоні 40-добового застосування левоноргестрелу і етинілестрадіолу та корекції тіотриазоліном виявлено зниження вмісту дієнових і трієнових кон'югатів, відповідно, на 53 і 38 \%, порівняно з ураженими тваринами, яким корекцію не проводили, а у гомогенаті печінки - 69 і 80 \%. При дії гепадифу також відмічено достовірне зниження інтенсивності генерування активних форм кисню мононуклеарними лейкоцитами крові, причому за семиразового уведення терапевтичної дози ацетамінофрену гепадифр практично нейтралізував його токсичну дію. Достовірно знижувалась концентрація дієнових (відповідно у 2,8 і 2,6 раза), і трієнових ( у 3,7 і 3,2 раза у плазмі крові уражених тварин. Аналогічну тенденцію зафріксовано нами і у гомогенаті печінки.

У таблиці 2 наведено результати впливу тіотриазоліну на вміст малонового альдегіду в плазмі крові і печінці щурів, уражених ацетамінофеном та комбінованими контрацептивами.

Показано, що введення коригуючих чинників зумовило зниження вмісту малонового альдегіду у плазмі крові і печінці уражених тварин. При одноразовому введенні ацетамінофрену і корекції тіотриазоліном вміст малонового альдегіду у плазмі крові тварин зменшився в 1,8 раза, при 7-добовому введенні - в
1,5 раза. Аналогічні зміни виявлено в печінці тварин - при корекції тіотриазоліном показники нормалізувались і майже не відрізнялись від рівня показників контрольної групи тварин. Ефективність гепадифру була ще вищою - досліджувані показники практично не відрізнялись від контрольних значень.

Корекція тіотриазоліном і гепадифом призвела до вірогідного зменшення вмісту окиснено модифікованих білків у плазмі крові і печінці уражених тварин (табл. 3). Зокрема, при одноразовому введенні ацетамінофену і корекції тіотриазоліном показник ОМБ $_{370}$ у плазмі крові знизився у 2,5 раза, порівняно 3 ураженими тваринами, а у печінці - у 1,5 раза. У групі тварин, яким ацетамінофен вводили 7 діб, встановлено зниження, відповідно, в 1,8 і 1,4 раза, цих показників у тварин контрольної групи. Уведення гепадифу мало ще більший позитивний ефект, що посприяло майже повній нормалізації вмісту окисненомодисрікованих білків.

Стосовно вмісту ОМБ ${ }_{430}$, то зміни були аналогічними - при одноразовому введенні у плазмі крові і печінці тварин цей показник вірогідно знизився в 1,8 раза, за семиразового введення терапевтичної дози - відповідно, в 1,9 і в 1,6 раза, порівняно 3 тваринами, яким корекцію не проводили.

Наступним етапом нашого дослідження було виявлення впливу тіотриазоліну на стан антиоксидантної системи. Як було показано вище, введення ацетамінофену та комбінованих контрацептивів пригнічувало фрункціональну активність більшості ферментних компонентів та зменшувало вміст неферментних компонентів антиоксидної системи. Уведення тіотриазоліну і гепадифру значною мірою нормалізувало їх стан.

Активність СОД у крові та печінці за дії ацетамінофену на тлі естрогенів та прогестинів зазнала зниження. Введення тіотриазоліну призвело до зрос-

Таблиця 2. Вміст малонового альдегіду в крові і печінці щурів за умов гострого токсичного та субхронічного ураження ацетамінофеном після 40-добового застосування етинілестрадіолу і левоноргестрелу та при корекції тіотриазоліном $(\mathrm{M} \pm \mathrm{m})$

\begin{tabular}{|c|c|c|c|c|c|c|c|c|}
\hline \multirow{3}{*}{ Показник } & \multirow{3}{*}{$\begin{array}{c}\text { Досліджуваний } \\
\text { матеріал }\end{array}$} & \multicolumn{7}{|c|}{ Група тварин } \\
\hline & & \multirow[t]{2}{*}{ 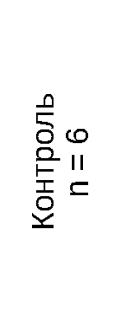 } & \multicolumn{2}{|c|}{$\begin{array}{c}\text { ацетамінофен } \\
\text { після 40-добового } \\
\text { введення } \\
\text { левоноргестрелу та } \\
\text { етинілестрадіолу }\end{array}$} & \multicolumn{2}{|c|}{$\begin{array}{c}\text { ацетамінофен } \\
\text { після 40-добового } \\
\text { введення лево- } \\
\text { норгестрелу, етиніл- } \\
\text { естрадіолу і корекції } \\
\text { тіотриазоліном } \\
\end{array}$} & \multicolumn{2}{|c|}{$\begin{array}{c}\text { ацетамінофен } \\
\text { після 40-добового } \\
\text { введення лево- } \\
\text { норгестрелу, етиніл- } \\
\text { естрадіолу і корекції } \\
\text { гепадифом }\end{array}$} \\
\hline & & & $\begin{array}{c}\text { Одноразово } \\
\mathrm{n}=6\end{array}$ & $\begin{array}{l}7 \text { діб } \\
\mathrm{n}=6\end{array}$ & $\begin{array}{c}\text { Одноразово } \\
n=6\end{array}$ & $\begin{array}{l}7 \text { діб } \\
\mathrm{n}=6\end{array}$ & $\begin{array}{c}\text { Одноразово } \\
n=6\end{array}$ & $\begin{array}{l}7 \text { діб } \\
\mathrm{n}=6\end{array}$ \\
\hline $\begin{array}{l}\text { Малоновий } \\
\text { альдегід, } \\
\text { мкмоль/л }\end{array}$ & Плазма крові & $\begin{array}{c}7,55 \pm \\
0,36\end{array}$ & $\begin{array}{c}16,08 \pm \\
0,81^{*}\end{array}$ & $\begin{array}{c}11,47 \pm \\
0,74^{*}\end{array}$ & $\begin{array}{l}8,93 \pm \\
0,68^{\#}\end{array}$ & $\begin{array}{l}7,64 \pm \\
0,74^{\#}\end{array}$ & $\begin{array}{l}8,22 \pm \\
0,37^{\#}\end{array}$ & $\begin{array}{l}7,57 \pm \\
0,43^{\#}\end{array}$ \\
\hline $\begin{array}{l}\text { Малоновий } \\
\text { альдегід, } \\
\text { мкмоль/кг }\end{array}$ & $\begin{array}{l}\text { Гомогенат } \\
\text { печінки }\end{array}$ & $\begin{array}{c}15,92 \pm \\
3,33\end{array}$ & $\begin{array}{c}28,03 \pm \\
3,78^{*}\end{array}$ & $\begin{array}{c}39,00 \pm \\
2,71^{*}\end{array}$ & $\begin{array}{c}17,25 \pm \\
3,63^{\#}\end{array}$ & $\begin{array}{l}16,7 \pm \\
2,01^{\#}\end{array}$ & $\begin{array}{c}16,68 \pm \\
1,14^{\#}\end{array}$ & $\begin{array}{c}16,15 \pm \\
0,86^{\#}\end{array}$ \\
\hline
\end{tabular}

ISSN 2312-0967. Pharmaceutical review. 2015. № 2 
Фармакологічні дослідження біологічно активних речовин Pharmacological researches of biologically active substances

Таблиця 3. Вміст окиснено-модифікованих білків в крові і печінці щурів за умов гострого токсичного та субхронічного ураження ацетамінофеном після 40-добового застосування етинілестрадіолу і левоноргестрелу та при корекції тіотриазоліном (M $\pm \mathrm{m})$

\begin{tabular}{|c|c|c|c|c|c|c|c|c|}
\hline \multirow{3}{*}{ Показник } & \multirow{3}{*}{$\begin{array}{c}\text { Досліджуваний } \\
\text { матеріал }\end{array}$} & \multicolumn{7}{|c|}{ Група тварин } \\
\hline & & \multirow[t]{2}{*}{ 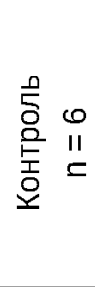 } & \multicolumn{2}{|c|}{$\begin{array}{c}\text { ацетамінофрен } \\
\text { після 40-добового } \\
\text { введення } \\
\text { левоноргестрелу та } \\
\text { етинілестрадіолу }\end{array}$} & \multicolumn{2}{|c|}{$\begin{array}{c}\text { ацетамінофен після } \\
\text { 40-добового введення } \\
\text { левоноргестрелу, } \\
\text { етинілестрадіолу } \\
\text { і корекції } \\
\text { тіотриазоліном } \\
\end{array}$} & \multicolumn{2}{|c|}{$\begin{array}{c}\text { ацетамінофен після } \\
\text { 40-добового введення } \\
\text { левоноргестрелу, } \\
\text { етинілестрадіолу і } \\
\text { корекції гепадифом }\end{array}$} \\
\hline & & & $\begin{array}{c}\text { одноразово } \\
n=6\end{array}$ & $\begin{array}{l}7 \text { діб } \\
\mathrm{n}=6\end{array}$ & $\begin{array}{c}\text { одноразово } \\
\mathrm{n}=6\end{array}$ & $\begin{array}{l}7 \text { діб } \\
\mathrm{n}=6\end{array}$ & $\begin{array}{c}\text { одноразово } \\
\mathrm{n}=6\end{array}$ & $\begin{array}{l}7 \text { діб } \\
\mathrm{n}=6\end{array}$ \\
\hline $\begin{array}{l}\text { ОМБ }_{370} \\
\text { ммоль/г } \\
\text { білка }\end{array}$ & плазма крові & $\begin{array}{c}0,77 \pm \\
0,02\end{array}$ & $\begin{array}{l}2,45 \pm \\
0,09 *\end{array}$ & $\begin{array}{l}1,45 \pm \\
0,03^{*}\end{array}$ & $\begin{array}{l}0,98 \pm \\
0,04 \text { *\# }\end{array}$ & $\begin{array}{l}0,81 \pm \\
0,01^{\#}\end{array}$ & $\begin{array}{l}0,83 \pm \\
0,05^{\#}\end{array}$ & $\begin{array}{l}0,80 \pm \\
0,02^{\#}\end{array}$ \\
\hline $\begin{array}{l}\mathrm{OMБ}_{430} \\
\text { ммоль/г } \\
\text { білка }\end{array}$ & плазма крові & $\begin{array}{c}0,48 \pm \\
0,04\end{array}$ & $\begin{array}{l}1,88 \pm \\
0,06^{\star}\end{array}$ & $\begin{array}{l}1,13 \pm \\
0,05^{\star}\end{array}$ & $\begin{array}{l}1,04 \pm \\
0,06^{\star \#}\end{array}$ & $\begin{array}{l}0,59 \pm \\
0,02^{\#}\end{array}$ & $\begin{array}{l}0,84 \pm \\
0,04 \text { *\# }\end{array}$ & $\begin{array}{l}0,52 \pm \\
0,03^{\#}\end{array}$ \\
\hline $\begin{array}{l}\text { ОМБ }_{370} \\
\text { ммоль/г } \\
\text { білка }\end{array}$ & $\begin{array}{l}\text { гомогенат } \\
\text { печінки }\end{array}$ & $\begin{array}{c}1,39 \pm \\
0,02\end{array}$ & $\begin{array}{l}2,96 \pm \\
0,07^{\star}\end{array}$ & $\begin{array}{l}2,04 \pm \\
0,05^{\star}\end{array}$ & $\begin{array}{l}1,92 \pm \\
0,03^{\star \#}\end{array}$ & $\begin{array}{l}1,46 \pm \\
0,07^{\#}\end{array}$ & $\begin{array}{l}1,55 \pm \\
0,06^{\#}\end{array}$ & $\begin{array}{l}1,42 \pm \\
0,04^{\#}\end{array}$ \\
\hline $\begin{array}{l}\text { ОМБ }_{430} \\
\text { ммоль/г } \\
\text { білка }\end{array}$ & $\begin{array}{l}\text { гомогенат } \\
\text { печінки }\end{array}$ & $\begin{array}{c}0,74 \pm \\
0,03\end{array}$ & $\begin{array}{l}2,82 \pm \\
0,08^{\star}\end{array}$ & $\begin{array}{l}1,56 \pm \\
0,07^{*}\end{array}$ & $\begin{array}{l}1,58 \pm \\
0,08^{\star \#}\end{array}$ & $\begin{array}{l}0,96 \pm \\
0,06^{\star \#}\end{array}$ & $\begin{array}{l}1,07 \pm \\
0,05^{\#}\end{array}$ & $\begin{array}{l}0,83 \pm \\
0,04^{\#}\end{array}$ \\
\hline
\end{tabular}

тання супероксиддисмутазної активності у сироватці крові у 2,7 раза, а печінки - у 3 раза порівняно 3 ураженими тваринами. За умов семидобового введення супероксиддисмутазна активність сироватки крові підвищувалась в 1,84 рази, а в печінці - в 1,91 раза порівняно з показником в уражених тварин. Ще ефективнішим був гепадифр, при дії якого показники наближались до рівня інтактних тварин.
Із таблиці 4 видно, що активність каталази у плазмі крові тварин при ураженні зростала, а у гомогенаті печінки знижувалась, тоді як при застосуванні коригуючих чинників наближалась до рівня тварин контрольної групи.

Вміст основного антиоксиданта плазми - церулоплазміну у плазмі крові тварин з гострим токсичним ураженням ацетамінофеном після 40-добового вве-

Таблиця 4. Активність супероксиддисмутази і каталази у плазмі крові та гомогенаті печінки щурів за умов гострого токсичного та субхронічного ураження ацетамінофеном після 40-добового застосування етинілестрадіолу і

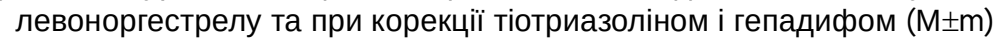

\begin{tabular}{|c|c|c|c|c|c|c|c|c|}
\hline \multirow{3}{*}{ Показник } & \multirow{3}{*}{$\begin{array}{c}\text { Досліджуваний } \\
\text { матеріал }\end{array}$} & \multicolumn{7}{|c|}{ Група тварин } \\
\hline & & \multirow[t]{2}{*}{ 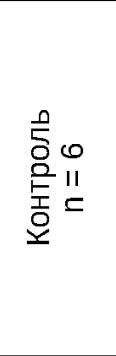 } & \multicolumn{2}{|c|}{$\begin{array}{c}\text { ацетамінофен } \\
\text { після 40-добового } \\
\text { введення } \\
\text { левоноргестрелу та } \\
\text { етинілестрадіолу }\end{array}$} & \multicolumn{2}{|c|}{$\begin{array}{c}\text { ацетамінофен } \\
\text { після 40-добового } \\
\text { введення } \\
\text { левоноргестрелу, } \\
\text { етинілестрадіолу } \\
\text { і корекції } \\
\text { тіотриазоліном }\end{array}$} & \multicolumn{2}{|c|}{$\begin{array}{c}\text { ацетамінофрен після } \\
\text { 40-добового введення } \\
\text { левоноргестрелу, } \\
\text { етинілестрадіолу і } \\
\text { корекції гепадифром }\end{array}$} \\
\hline & & & $\begin{array}{c}\text { одно- } \\
\text { разово } \\
\mathrm{n}=6\end{array}$ & $\begin{array}{l}7 \text { діб } \\
\mathrm{n}=6\end{array}$ & $\begin{array}{c}\text { одно- } \\
\text { разово } \\
\mathrm{n}=6\end{array}$ & $\begin{array}{l}7 \text { діб } \\
\mathrm{n}=6\end{array}$ & $\begin{array}{c}\text { одно- } \\
\text { разово } \\
\mathrm{n}=6\end{array}$ & $\begin{array}{l}7 \text { діб } \\
\mathrm{n}=6\end{array}$ \\
\hline $\begin{array}{l}\text { Супероксид- } \\
\text { дисмутаза, } \\
\text { ум.од./л } \\
\end{array}$ & $\begin{array}{l}\text { сироватка } \\
\text { крові }\end{array}$ & $\begin{array}{c}1,24 \pm \\
0,02\end{array}$ & $\begin{array}{l}0,36 \pm \\
0,04^{\star}\end{array}$ & $\begin{array}{l}0,64 \pm \\
0,09 *\end{array}$ & $\begin{array}{c}0,96 \pm \\
0,06\end{array}$ & $\begin{array}{l}1,18 \pm \\
0,05^{\#}\end{array}$ & $\begin{array}{c}0,98 \pm \\
0,05\end{array}$ & $\begin{array}{l}1,21 \pm \\
0,07^{\#}\end{array}$ \\
\hline $\begin{array}{l}\text { Супероксид- } \\
\text { дисмутаза, } \\
\text { ум.од./кг }\end{array}$ & $\begin{array}{l}\text { гомогенат } \\
\text { печінки }\end{array}$ & $\begin{array}{c}4,27 \pm \\
0,07\end{array}$ & $\begin{array}{l}1,26 \pm \\
0,19 *\end{array}$ & $\begin{array}{l}2,16 \pm \\
0,34^{*}\end{array}$ & $\begin{array}{l}3,83 \pm \\
0,11^{\#}\end{array}$ & $\begin{array}{l}4,12 \pm \\
0,09^{\#}\end{array}$ & $\begin{array}{l}3,88 \pm \\
0,11^{\#}\end{array}$ & $\begin{array}{l}4,16 \pm \\
0,05^{\#}\end{array}$ \\
\hline $\begin{array}{l}\text { Каталаза, } \\
\text { мкат/л }\end{array}$ & $\begin{array}{l}\text { сироватка } \\
\text { крові }\end{array}$ & $\begin{array}{c}0,19 \pm \\
0,01 \\
\end{array}$ & $\begin{array}{l}0,96 \pm \\
0,05^{\star}\end{array}$ & $\begin{array}{l}0,79 \pm \\
0,03^{\star}\end{array}$ & $\begin{array}{l}0,45 \pm \\
0,02^{\star \#}\end{array}$ & $\begin{array}{l}0,38 \pm \\
0,02^{\star \#} \\
\end{array}$ & $\begin{array}{l}0,27 \pm \\
0,05^{\#} \\
\end{array}$ & $\begin{array}{l}0,21 \pm \\
0,02^{\#}\end{array}$ \\
\hline $\begin{array}{l}\text { Каталаза, } \\
\text { мкат/кг }\end{array}$ & $\begin{array}{l}\text { гомогенат } \\
\text { печінки }\end{array}$ & $\begin{array}{c}58,79 \pm \\
2,38 \\
\end{array}$ & $\begin{array}{c}19,76 \pm \\
0,82^{*}\end{array}$ & $\begin{array}{c}26,63 \pm \\
1,07^{*} \\
\end{array}$ & $\begin{array}{c}58,38 \pm \\
2,14^{\#} \\
\end{array}$ & $\begin{array}{c}58,16 \pm \\
2,20^{\#} \\
\end{array}$ & $\begin{array}{c}56,23 \pm \\
1,34^{\#} \\
\end{array}$ & $\begin{array}{c}57,31 \pm \\
1,56^{\#} \\
\end{array}$ \\
\hline
\end{tabular}

ISSN 2312-0967. Фармацевтичний часопис. 2015. № 2 
Фармакологічні дослідження біологічно активних речовин

Pharmacological researches of biologically active substances

дення естрогенів і прогестинів зменшився на 59 \%, а корекція тіотриазоліном супроводжувалась збільшенням концентрації мідьоксидази в 2,2 раза, відносно уражених щурів, причому показник лише на 12 \% відрізнявся від рівня тварин контрольної групи (табл. 5). Аналогічна тенденція до нормалізації, проте дещо менш виражена, зафріксована і у групі тварин, яким АФ вводили 7 діб.

Пероксидазна активність крові при корекції тіотриазоліном знизилась, відповідно, на 159 і $162 \%$ порівняно з показниками уражених тварин. ще більший ефект проявив гепадиф, уведення якого супроводжувалось нормалізацією пероксидазної активності крові і концентрації церулоплазміну.

Щодо стану глутатіонової системи, то вона також зазнавала істотних змін. При дії ацетамінофену після введення естрогенів і прогестинів активність глута- тіонпероксидази вірогідно знижувалась порівняно 3 тваринами контрольної групи у 3,6 раза, а введення тіотриазоліну призвело до підвищення активності у 3,1 раза, порівняно з ураженими тваринами.

Показник активності глутатіонредуктази зріс у 2,4 раза відносно уражених тварин і становив 82 \% від норми. Виявлено, що концентрація відновленого глутатіону, яка зменшувалась при дії ацетамінофрену, за корекції тіотриазоліном збільшилась у 3,2 раза і становила 79 \% від рівня тварин контрольної групи (табл. 6).

При дії ацетамінофену у вищій тепапевтичній дозі впродовж 7 діб на фроні 40-добового введення комбінованих контрацептивів також констатовано у крові тварин пригнічення глутатіонової ланки антиоксидантного захисту. Активність глутатіонпероксидази становила 54,7 \% від рівня тварин контрольної гру-

Таблиця 5. Пероксидазна активність крові та вміст церулоплазміну у плазмі крові щурів за умов гострого токсичного та субхронічного ураження ацетамінофеном після 40-добового застосування етинілестрадіолу і левоноргестрелу та при корекції тіотриазоліном і гепадифом, $(\mathrm{M} \pm \mathrm{m})$

\begin{tabular}{|c|c|c|c|c|c|c|c|c|}
\hline \multirow{3}{*}{ Показник } & \multirow{3}{*}{$\begin{array}{c}\text { Дослі- } \\
\text { джуваний } \\
\text { матеріал }\end{array}$} & \multicolumn{7}{|c|}{ Група тварин } \\
\hline & & \multirow[t]{2}{*}{ 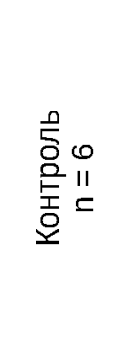 } & \multicolumn{2}{|c|}{$\begin{array}{c}\text { ацетамінофрен } \\
\text { після 40-добового } \\
\text { введення } \\
\text { левоноргестрелу та } \\
\text { етинілестрадіолу }\end{array}$} & \multicolumn{2}{|c|}{$\begin{array}{c}\text { ацетамінофрен } \\
\text { після 40-добового } \\
\text { введення } \\
\text { левоноргестрелу, } \\
\text { етинілестрадіолу } \\
\text { і корекції } \\
\text { тіотриазоліном }\end{array}$} & \multicolumn{2}{|c|}{$\begin{array}{c}\text { ацетамінофен } \\
\text { після 40-добового } \\
\text { введення } \\
\text { левоноргестрелу, } \\
\text { етинілестрадіолу і } \\
\text { корекції гепадифом }\end{array}$} \\
\hline & & & $\begin{array}{c}\text { Одно- } \\
\text { разово } \\
\mathrm{n}=6\end{array}$ & $\begin{array}{l}7 \text { діб } \\
\mathrm{n}=6\end{array}$ & $\begin{array}{c}\text { Одно- } \\
\text { разово } \\
\mathrm{n}=6\end{array}$ & $\begin{array}{l}7 \text { діб } \\
\mathrm{n}=6\end{array}$ & $\begin{array}{c}\text { Одно- } \\
\text { разово } \\
\mathrm{n}=6 \\
\end{array}$ & $\begin{array}{l}7 \text { діб } \\
\mathrm{n}=6\end{array}$ \\
\hline $\begin{array}{l}\text { Пероксидазна } \\
\text { активність } \\
\text { крові, мкмоль·л }\end{array}$ & кров & $\begin{array}{c}282,60 \pm \\
6,32\end{array}$ & $\begin{array}{c}615,05 \pm \\
18,9^{*}\end{array}$ & $\begin{array}{c}512,5 \pm \\
2,19^{*}\end{array}$ & $\begin{array}{l}386,95 \pm \\
17,06^{\star \#}\end{array}$ & $\begin{array}{l}316,59 \pm \\
14,54^{\star \#}\end{array}$ & $\begin{array}{c}318,66 \pm \\
8,14^{\#}\end{array}$ & $\begin{array}{c}296,72 \pm \\
11,09^{\#}\end{array}$ \\
\hline $\begin{array}{l}\text { Церулоплазмін, } \\
\text { мг/л }\end{array}$ & $\begin{array}{l}\text { плазма } \\
\text { крові }\end{array}$ & $\begin{array}{c}251,92 \pm \\
2,68\end{array}$ & $\begin{array}{c}103,33 \pm \\
2,01^{*}\end{array}$ & $\begin{array}{c}136,9 \pm \\
1,76^{*}\end{array}$ & $\begin{array}{c}221,90 \pm \\
5,57 \text { *\# }\end{array}$ & $\begin{array}{c}174,86 \pm \\
5,65^{\star \#}\end{array}$ & $\begin{array}{c}233,64 \pm \\
2,77^{\#}\end{array}$ & $\begin{array}{c}224,07 \pm \\
3,11^{\#}\end{array}$ \\
\hline
\end{tabular}

Таблиця 6. Активність глутатіонпероксидази, глутатіонредуктази та вміст відновленого глутатіону щурів за умов гострого токсичного та субхронічного ураження ацетамінофеном після 40-добового застосування етинілестрадіолу і левоноргестрелу та при корекції тіотриазоліном і гепадифом, $(\mathrm{M} \pm \mathrm{m})$

\begin{tabular}{|c|c|c|c|c|c|c|c|c|}
\hline \multirow{3}{*}{ Показник } & \multirow{3}{*}{$\begin{array}{c}\text { Досліджуваний } \\
\text { матеріал }\end{array}$} & \multicolumn{7}{|c|}{ Група тварин } \\
\hline & & \multirow[t]{2}{*}{ 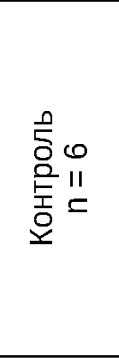 } & \multicolumn{2}{|c|}{$\begin{array}{c}\text { ацетамінофен } \\
\text { після 40- } \\
\text { добового } \\
\text { введення } \\
\text { левоноргестрелу } \\
\text { та } \\
\text { етинілестрадіолу } \\
\end{array}$} & \multicolumn{2}{|c|}{$\begin{array}{c}\text { ацетамінофен } \\
\text { після 40-добового } \\
\text { введення } \\
\text { левоноргестрелу, } \\
\text { етинілестрадіолу } \\
\text { і корекції } \\
\text { тіотриазоліном }\end{array}$} & \multicolumn{2}{|c|}{$\begin{array}{c}\text { ацетамінофен } \\
\text { після 40-добового } \\
\text { введення } \\
\text { левоноргестрелу, } \\
\text { етинілестрадіолу, } \\
\text { і корекції } \\
\text { гепадифом } \\
\end{array}$} \\
\hline & & & $\begin{array}{c}\text { одно- } \\
\text { разово } \\
\mathrm{n}=6\end{array}$ & $\begin{array}{l}7 \text { діб } \\
\mathrm{n}=6\end{array}$ & $\begin{array}{c}\text { одно- } \\
\text { разово } \\
\mathrm{n}=6\end{array}$ & $\begin{array}{l}7 \text { діб } \\
\mathrm{n}=6\end{array}$ & $\begin{array}{c}\text { одно- } \\
\text { разово } \\
\mathrm{n}=6\end{array}$ & $\begin{array}{l}7 \text { діб } \\
\mathrm{n}=6\end{array}$ \\
\hline $\begin{array}{l}\text { Глутатіонпероксидаза, } \\
\text { ммоль/ хв·кг }\end{array}$ & $\begin{array}{l}\text { гомогенат } \\
\text { печінки }\end{array}$ & $\begin{array}{c}0,242 \pm \\
0,011 \\
\end{array}$ & $\begin{array}{l}0,066 \pm \\
0,007^{\star}\end{array}$ & $\begin{array}{l}0,132 \pm \\
0,01^{*}\end{array}$ & $\begin{array}{c}0,208 \pm \\
0,02^{\#}\end{array}$ & $\begin{array}{l}0,220 \pm \\
0,021^{\#}\end{array}$ & $\begin{array}{l}0,196 \pm \\
0,013^{\#}\end{array}$ & $\begin{array}{l}0,211 \pm \\
0,012^{\#}\end{array}$ \\
\hline $\begin{array}{l}\text { Глутатіонредуктаза, } \\
\text { ммоль/ кг·хв }\end{array}$ & $\begin{array}{l}\text { гомогенат } \\
\text { печінки }\end{array}$ & $\begin{array}{c}77,44 \pm \\
3,42\end{array}$ & $\begin{array}{c}26,54 \pm \\
2,18^{\star}\end{array}$ & $\begin{array}{l}48,26 \pm \\
0,53^{*}\end{array}$ & $\begin{array}{l}63,14 \pm \\
2,75^{\star \#}\end{array}$ & $\begin{array}{l}71,27 \pm \\
3,38^{\#}\end{array}$ & $\begin{array}{l}60,11 \pm \\
1,05^{\star \#}\end{array}$ & $\begin{array}{c}69,78 \pm \\
1,56^{\#}\end{array}$ \\
\hline $\begin{array}{l}\text { Відновлений глутатіон, } \\
\text { ммоль/ кг }\end{array}$ & $\begin{array}{l}\text { гомогенат } \\
\text { печінки }\end{array}$ & $\begin{array}{c}4,27 \pm \\
0,04\end{array}$ & $\begin{array}{l}1,48 \pm \\
0,28^{*}\end{array}$ & $\begin{array}{l}3,11 \pm \\
0,015^{\star}\end{array}$ & $\begin{array}{l}3,36 \pm \\
0,10^{* \#}\end{array}$ & $\begin{array}{l}3,72 \pm \\
0,08^{\#}\end{array}$ & $\begin{array}{l}3,11 \pm \\
0,12^{\star \#}\end{array}$ & $\begin{array}{l}3,66 \pm \\
0,07^{\#}\end{array}$ \\
\hline
\end{tabular}

ISSN 2312-0967. Pharmaceutical review. 2015. № 2 
пи, активність глутатіонредуктази - 62,4 \%, а концентрація відновленого глутатіону - 72,8 \% від норми. Введення тіотриазоліну виявило протекторний вплив на досліджувані показники у крові щурів: активність глутатіонпероксидази підвищилась у 1,7 раза, глутатіонредуктази - у 1,48 раза, а концентрація відновленого глутатіону - в 1,2 раза, що може бути наслідком зв'язування реактивних метаболітів ацетаміносрену 3 вільними сульфгідрильними групами тіотриазоліну, а отже, збереження резерву відновленого глутатіону. Корекція гепадифом також привела до позитивних результатів, однак він був менш ефективним, ніж тіотриазолін, що, очевидно, пов'язане з механізмом дії цих препаратів.

Висновки. Використання тіотриазоліну та гепадисру в тварин \$з токсичним ураженням ацетаміносреном після тривалого уведення естрогенів і прогестинів супроводжується пригніченням утворення активних форм кисню мононуклеарними лейкоцитами, зниженням інтенсивності процесів ліпідної і білкової пероксидації, нормалізацією ферментної і неферментної ланок антиоксидантної системи.

\section{Література}

1. Kehlet $\mathrm{H}$. Are perioperative nonsteroidal antiinflammatory drugs ulcerogenic in the short term? H. Kehlet, J. B. Dahl // Drugs. - 1992. - № 44. - P. 38-41. 2. Effects of non-steroidal anti-inflammatory drugs on patient-controlled analgesia morphine side effects: metaanalysis of randomized controlled trials / E. Marret, O. Kurdi, P. Zufferey, F. Bonnet // Anesthesiology. - 2005. - Vol. 102, № 6. - P. 1249-1260.

3. Rectal paracetamol has a significant morphine-sparing effect after hysterectomy / T. F. Cobby, I. M. Crighton, K. Kyriakides, G. J. Hobbs // Br. J. Anaesth. - 1999. № 83. - P. 253-256.

4. Delbos A. The morphine-sparing effect of propacetamol in orthopedic postoperative pain / A. Delbos. E. Boccard // J. Pain Symptom Manage. - 1995. - № 10. - P. 279-286. 5. Peduto V. A. Efficacy of propacetamol in the treatment of postoperative pain. Morphine-sparing effect in orthopedic surgery. Italian Collaborative Group on Propacetamol / V. A. Peduto, M. Ballabio, S. Stefanini // Acta Anaesthesiol. Scand. - 1998. - № 42. - P. 293-298.

6. Intravenous administration of propacetamol reduces morphine consumption after spinal fusion surgery / J. Hernandez-Palazon, J. A. Tortosa, J. F. Martinez-Lage [et al.] // Anesth. Analg. - 2001. - № 92. - P. 1473-1476.

7. Diclofenac and/or propacetamol for postoperative pain management after cesarean delivery in patients receiving patient controlled analgesia morphine / S. M. Siddik, M. T. Aouad, M. I. Jalbout [et al.] // Reg. Anesth. Pain Med. -2001. - № 26. - P. 310-315.

8. Intravenous $\mathrm{N}$-acetylcysteine: the treatment of choice for paracetamol poisoning / L. F. Prescott, R. N. Illingworth, J. A. Critchley, A. T. Proudfoot // B. M. J. - 1979. - № 2. P. 1097-1100.

9. Dargan P. I. Measuring paracetamol concentrations in all patients with drug overdose or altered consciousness: does it change outcome? / P. I. Dargan, S. L. Ladhani, A. L. Jones // Emerg. Med. J. -2001. - № 18. - P. 178182

10. Gyamlani G. G. Acetaminophen toxicity: suicidal vs accidental / G. G. Gyamlani, C. R. Parikh // Crit. Care. 2002. - № 6. - P. 155-159.

11. Ивашкин В. Т. Диагностика и лечение неалкогольной жировой болезни печени : методические рекомендации / В. Т. Ивашкин, О. М. Драпкина, Ю. О. Шульпекова. М. : М-Вести, 2009. - 20 с.
12. Минушкин О. Н. Некоторые гепатопротекторы в лечении заболеваний печени / О. Н. Минушкин // Лечащий врач. - 2002. - № 6. - С. 55-58.

13. Садыков К. Б. Опыт применения гепатопротектора Гепадиср при хронических вирусных гепатитах В и С / К. Б. Садыков // Медицина. - 2003. - № 5. - С. 46-50. 14. Чекман І. С. Клінічна фрітотерапія / I. С. Чекман. - К. : Тов. Рада, 2006. - 628 с.

15. J. A. Ibdah, P. Perlegas, Y. Zhao [et al.] Mice heterozygous for a defect in mitochondrial trifunctional protein develop hepatic steatosis and insulin resistance / J. A. Ibdah, P. Perlegas, Y. Zhao [et al.] // Gastroenterology. - 2005. - Vol. 128. - P. 1381-1390.

16. The role of adenomethionine (S-adenosylmethionine) in the prevention of cyclosporine-induced cholestasis / S. Nei, S. Signorelli, D. Sterna [et al.] // Clin. drug Invest. 2002. - Vol. 22. - P. 191-195.

17. Кожем'якін Ю. М. Науково-практичні рекомендації з утримання лабораторних тварин та роботи з ними / Ю. М. Кожем'якін, О. С. Хромов, М. А. Філоненко. - К. : Авіцена, 2002. - 156 с.

18. Сопоставление различных подходов к определению перекисного окисления липидов в гептанизопропанольных экстрактах крови / И. А. Волчегорский, А. Г. Налимов, Б. Г. Яровинский, Р. И. Лившиц // Вопросы мед. химии. - 1989. - № 1. - С. 127.

19. Владимиров Ю. А. Перекисное окисление липидов В биологических мембранах / Ю. А. Владимиров, А. И. Арчаков. - М., 1972. - 252 с.

20. Кругликова Г. О. Глутатіонпероксидазна та глутатіонредуктазна активність печінки щурів після введення селеніту натрію / Г. О. Кругликова, Ц. М. Штутман // Укр. біохім. журн. - 1976. - Т. 48, № 2. - C. 227-233.

21. Ellman George L. Tissue sulfhydril groups / L. Ellman George // Arch. of Biochem. and Biophys. - 1959. - Vol. 82, № 1. - P. 70-77.

22. Мещишен І. Ф. Метод визначення окислювальної модифрікації білків плазми (сироватки) крові / І. Ф. Мещишен // Буковинський мед. вісн. - 1998. - 2, № 1. - C. 156-158.

23. Beachamp C. Superoxide dismutase: improved assay and assay a plicable to acrilamide gells / C. Beachamp, J. Fridovich // Analyt. Biochem. - 1974. -Vol. 44, № 7. P. 276-279. 
Фармакологічні дослідження біологічно активних речовин

Pharmacological researches of biologically active substances

24. Чевари С. Роль супероксиддисмутазы в окислительных процессах клетки и метод определения ее в биологическом материале / С. Чевари, И. Чаба, Й. Секей // Лаб. дело. - 1985. - № 11. - С. 678-681.

25. Определение активности каталазы / М. А. Королюк, Л. И. Иванова, И. Г. Майорова, В. Е. Токарев // Лабораторное дело. - 1988. - № 1. - С. 16-19.

26. Колб В. Г. Справочник по клинической химии / В. Г. Колб, В. С. Камышников. - Минск, 1982. - 311 с.
27. Попов Т. Метод определения пероксидазной активности крови / Т. Попов, Л. Нейковска // Гигиена и санитария. - 1971. - № 10. - С. 89-93.

28. Чечина О. Е. Роль цитокинов в редокс-зависимой регуляции апоптоза / О. Е. Чечина, А. К. Биктасова, Е.В.Сазонова, О. Б. Жукова, Т. С. Прохоренко, И.В.Крат, Н. Ю. Часовских, В. В. Новицкий, Н.В.Рязанцева // Бюллетень сибирской медицины. - 2009. - № 2. C. $67-72$.

\section{ОСОБЕННОСТИ ПОКАЗАТЕЛЕЙ СВОБОДНОРАДИКАЛЬНОГО ОКИСЛЕНИЯ И АНТИОКСИДАНТНОЙ СИСТЕМЫ У ЖИВОТНЫХ В УСЛОВИЯХ ОСТРОГО ТОКСИЧЕСКОГО И СУБХРОНИЧЕСКОГО ПОРАЖЕНИЯ АЦЕТАМИНОФЕНОМ НА ФОНЕ ДЛИТЕЛЬНОГО ПРИМЕНЕНИЯ ЭСТРОГЕНОВ И ПРОГЕСТИНА ПРИ КОРРЕКЦИИ ТИОТРИАЗОЛИНОМ И ГЕПАДИФОМ}

\section{И. Б. Ивануса}

Тернопольский государственный медицинский университет имени И. Я. Горбачевского

Резюме: судя по результатам исследований, можно утверждать о активации пОл у животных, пораженных ацетаминофеном на фоне длительного введения эстрогенов и прогестинов. Об этом свидетельствует повышение концентрации активных фрорм кислорода, которые продуцируются мононуклеарными лейкоцитами, содержания продуктов липопероксидации: малонового альдегида, диеновых и триенових конъюгатов. Способность корректирующих фракторов тормозить образование этих продуктов в плазме и гомогенате может косвенно свидетельствовать о антиокислительных свойствах препаратов, поэтому представляло интерес исследовать влияние тиотриазолина и гепадифа на активность этих процессов у крыс, пораженных ацетаминофеном на фроне длительного введения эстрогенов и прогестинов.

Ключевые слова: ацетаминофен, тиотриазолин, гепадиф, свободнорадикальное окисление липидов и белков, антиоксидантная система.

\section{FEATURES OF FREE RADICAL OXIDATION AND ANTIOXIDANT SYSTEM PARAMETRS OF ANIMALS AT ACUTE TOXIC AND SUBCHRONIC POISONING BY ACETAMINOPHEN WITH PROLONGED USAGE OF ESTROGEN AND PROGESTIN AT THE CORRECTION BY THIOTRIAZOLINE AND HEPADIF}

\section{B. Ivanusa}

Ternopil State Medical University by I. Ya. Horbachevsky

Summary: activation of lipid peroxidation of animals at poisoning by acetaminophen with prolonged usage of estrogen and progestin are investigated. This is evidenced by increased concentration of reactive oxygen species by mononuclear leukocytes, the content of lipid peroxidation products: malondialdehyde, diene and triene conjugates. The ability of the corrective factors inhibits the formation of these products in the plasma and homogenate can indirectly evidenced about the antioxidant properties of the drug. So it is interested to investigate the influence of thiotriazoline and hepadif on activity of these processes in rats, which are poisoned by acetaminophen with prolonged usage of estrogen and progestin.

Key words: acetaminophen, thiotriazoline, hepadif, free radical oxidation of lipids and proteins, antioxidant system. 